\title{
Gente rara
}

\section{cuento en clave de autoficción}

Yo es otro.

Todorov

Mi nombre es Hernando Escobar, eso dice mi cédula. No es que sea esa persona, como usted puede ver; pero sé bien adónde va su pregunta y por eso le respondo: mi nombre es Hernando Escobar, bailarina de El Gril y profesora de literatura, en ese orden. Tal vez ha estado ahí, el sitio se ha hecho conocido. Una vez salió un artículo en El Tiempo. No hablaron de mí, cuestión de oportunidad. Si hubiera estado ese día... No sabemos si Julio, el dueño... o si el periodista... El hecho es que salió una foto de Verónica, amiga mía, una chica-chica. Su cuerpo completamente horizontal, un pie en el piso, un brazo en el aire, no se ve el otro brazo, con el que se sostiene del tubo, entonces parece que estuviera levitando, como las ayudantes de mago. El pelo cae todo, todo, y resplandece porque atrás hay una luz. Verónica es muy buena en eso. Se merece la publicidad, no digo que no, aunque apenas lleva un año. Apenas... bueno... Las chicas no duran mucho. Llevo cinco años y soy la más veterana. Ayudo con las cuentas, y hace años que Julio no me hace bromas... molestas. Lo hacía para desquitarse. Le dije: Fernanda Escobar. Con esta misma voz, no tengo otra: tengo dos nombres pero una sola voz. Él no se dio cuenta. Usted no se habría dado cuenta si no es

\section{Hernando Escobar Vera}

Universidad Pedagógica y Tecnológica de Colombia. Profesor de Literatura, estudiante de doctorado en Literatura Hispanoamericana y director de los talleres de creación literaria Tintababelia. nandoev@yahoo.es 
por... Si ahora tengo este cuerpo, imagínese hace cinco años. Pero todo se sabe... Y a él no le gustó haberme visto con esos ojos: se sintió burlado, y tal vez quiso que me aburriera y renunciara. No parece, pero tengo la piel dura. Se va endureciendo una. Ninguno de mis trabajos es fácil: lidiar con borrachos o con estudiantes. De día enseño en una universidad privada, o sea, soy algo así como la mucama de muchachos que se creen de mejor estrato del que son. No me dicen profesora; me dicen Fernanda o Fernandita, y me tutean. Y los colegas también me llaman por mi verdadero nombre; algunos me tratan respetuosamente: profesora Fernanda o profesora Escobar, otros me dicen Fernandita y me tutean. Creo que esos son los que no saben. Pero todo termina por saberse. Así como usted viene, me pide la cédula y me hace cara de conque, conque... Imagínese: afiliarse a la EPS, a las pensiones y cesantías, firmar contrato, secretarias en un día aburrido, el papeleo de siempre... y de pronto a una se le ilumina la cara y les dice a las demás Sí saben, ¿no? Conque, conque. Y de ahí a la Decana y a su círculo de lameculos, y a los lameculos de los lameculos. No me importa, ya le dije: tengo la piel dura. Fue ese, ¿cierto? El que está pateando el poste. ¿Qué es eso? ¿Taekwondo? Buen cuerpo, eso sí, pero es casi un mocoso. Una mira. Yo miro en todas direcciones, $\mathrm{y}$ con frecuencia hay alguno con el ego grande, que se cree que una mirada es más que una mirada, se pone intenso y me da por mostrarle mi cédula e impostar la voz, poner esa fea voz que no es la mía, para que no joda y sí, lo reconozco, para joderlo: a veces digo mi otro nombre para joder a alguien. Pero este quedó más herido que avergonzado y fue y les contó a otros del barrio, y ahora les parece a todos que los miro con morbo, y vienen y me gritan en la ventana que soy un acosador y un pervertido.

Escogí esta casa por la vista al parque, ¿y ahora resulta que no puedo mirar por la ventana? Tengo la piel dura, ya le dije: que vayan a mi trabajo, que le digan a la Decana, que les digan a los estudiantes el otro nombre de su mucama, que salga una foto mía entre signos de interrogación. De la Universidad no me van a echar: está eso del libre desarrollo de la personalidad y los derechos LGBTI. Y a Julio hasta le puede gustar la publicidad: profesora de día, bailarina de noche. Vamos a El Gril a ver a la profesora universitaria, diría la clientela. Todos en primera fila para verme. Tendría que bailar con un vestido estereotípico de profesora, bien sexy. Gafas, eso no faltaría. Hasta otro artículo en El Tiempo... ¿se imagina? Pobre Decana, eso sí: va a pensar Por qué no me tocó la otra profesora, la activista, a la que se le nota en la voz y le da fama a la Universidad de ser muy posmoderna; en cambio le toqué yo, bailarina de gril. Si quiere dígale eso al muchacho, que haga lo que quiera. Y que siga pateando el poste: cuando me canse de mirar hacia adentro, voy a mirar hacia afuera y qué voy a ver, dígame, pues al loco que se la pasa pateando el poste, porque eso sí, la gente rara llama la atención. 